\title{
Pengaruh intensitas informasi teman sebaya, literasi ekonomi, dan kontrol diri terhadap pembelian impulsif pada genbi Universitas Negeri Malang periode 2020-2021
}

\author{
Risa Ardianti, Rizza Megasari* \\ Universitas Negeri Malang, Jl. Semarang No. 5 Malang, Jawa Timur, Indonesia \\ *Penulis korespondensi, Surel: rizza.megasari.fe@um.ac.id
}

Paper received: 6-8-2021; revised: 20-8-2021; accepted: 28-8-2021

\begin{abstract}
This study aims to measure and analyze the effect of peer information intensity, economic literacy, and self-control on impulsive buying at GenBI State University of Malang for the period 2020-2021. This research uses descriptive research with quantitative methods. The data is obtained by distributing the instruments located on the Google Form link by calling the respondent's Whatsapp number. Based on the research results, it was decided that the three independent variables have an effect on impulsive buying. Peer information intensity is the most dominant in influencing impulsive buying. The third variation of the independent variables can explain impulsive buying by $59.3 \%$.
\end{abstract}

Keywords: GenBI; peer information intensity; self-control; economic literacy; impulsive buying

\begin{abstract}
Abstrak
Penelitian ini bertujuan untuk mengukur dan menganalisis pengaruh intensitas informasi teman sebaya, literasi ekonomi, dan kontrol diri terhadap pembelian impulsif pada GenBI Universitas Negeri Malang periode 2020-2021. Penelitian ini menggunakan jenis penelitian deskriptif dengan metode kuantitatif. Data diperoleh dengan menyebarkan instrumen yang terletak pada link Google Form dengan menghubungi nomor Whatsapp responden. Berdasarkan hasil penelitian, diputuskan bahwa ketiga variabel independen berpengaruh terhadap pembelian impulsif. Intensitas informasi teman sebaya paling dominan dalam mempengaruhi pembelian impulsif. Variasi ketiga variabel bebas dapat menjelaskan pembelian impulsif sebesar 59,3\%.
\end{abstract}

Kata kunci: GenBI; intensitas informasi teman sebaya; kontrol diri; literasi ekonomi; pembelian impulsif

\section{Pendahuluan}

Menurut pendapat Rozaini \& Ginting (2019:2) mahasiswa telah diberi kepercayaan serta tanggung jawab oleh orang tua mereka untuk mengelola keuangan selama berada di kota rantau. Oleh sebab itu, sebelum berbelanja, mahasiswa akan menyusun perencanaan dengan membuat daftar belanja, di mana ia akan mengutamakan keperluan yang paling mendesak untuk dibeli. Pernyataan tersebut sesuai dengan pendapat dari Sarafino (2011, dalam Kurniasari, 2020:6) membuat perencanaan sebelum berbelanja dengan menyusun daftar belanja maupun daftar rincian biaya yang akan dikeluarkan membuat seseorang menjadi lebih berhati-hati saat sedang berbelanja, terutama saat membeli kebutuhan primer. Berbelanja merupakan salah satu tindakan yang dapat dijalankan masyarakat dalam upaya memenuhi kebutuhannya, tidak terkecuali bagi para mahasiswa. Pernyataan tersebut didukung dengan pendapat dari Kosyu, dkk (2014:2) yang menyatakan bahwa, seseorang berbelanja tidak hanya untuk memenuhi kebutuhan, tetapi juga sebagai sarana menghilangkan rasa bosan. Sehingga, Larasati \& Budiani (2014:1) memaparkan pendapatnya bahwa, berbelanja bagi sebagian orang merupakan suatu kegiatan yang menyenangkan dan membuat perasaan menjadi bahagia 
apabila ia memperoleh barang yang diinginkan, sehingga menjadi kepuasan tersendiri bagi orang tersebut. Sesuai dengan penjelasan dari Pratiwi (2017:99) ada banyak hal tidak terduga yang dapat mempengaruhi keputusan seorang mahasiswa saat melakukan pembelian meskipun ia telah membuat daftar barang yang akan dibeli, hal ini akan mendorong terjadinya pembelian impulsif.

Menurut Ernayanti \& Marheni (2019:228) impulse buying merupakan tindakan individu yang tidak melakukan perencanaan ketika berbelanja. Pernyataan tersebut didukung dengan pendapat dari Susanta (2007:78 dalam Noneng, dkk, 2020:95) yang menyatakan, bahwa mayoritas konsumen di Indonesia memiliki kebiasaan dalam melakukan sesuatu yang tidak terencana, sehingga biasanya mereka sering membuat keputusan pada menit terakhir dalam berbelanja yang mengakibatkan terjadinya pembelian impulsif. Sejalan dengan pendapat tersebut, Ernayanti \& Marheni (2019:228) menyatakan bahwa, pembelian impulsif atau juga dapat dikatakan sebagai unplanned purchase dapat terjadi apabila individu sedang melihat sebuah barang dan seketika berkeinginan untuk membeli barang tersebut, sehingga saat itu juga ia akan membuat keputusan untuk melakukan pembelian. Merujuk pada pemaparan dari Putri (2019:3) Realita mengenai gejala pembelian impulsif dapat menimpa kalangan pelajar di perguruan tinggi, hal ini terjadi dikarenakan mereka belum bisa menghasilkan pendapatan sendiri untuk memenuhi kebutuhannya. Adapun indikator yang digunakan untuk mengukur pembelian impulsif antara lain: 1) spontanitas; 2) keinginan yang kuat dan intensitas dalam berbelanja; 3) emosi positif serta stimulus ketika berbelanja; 4) ketidakpedulian akan akibat yang ditimbulkan dari pembelian suatu produk.

Berdasarkan hasil wawancara tidak terstruktur yang peneliti lakukan sebelumnya pada beberapa mahasiswa GenBI Universitas Negeri Malang periode 2020-2021, diperoleh informasi bahwa para mahasiswa tersebut selama penerimaan beasiswa (yang artinya mereka mendapatkan tambahan uang saku dan memiliki kelebihan uang) tidak jarang mengalami pembelian yang tidak terduga (impulsive buying). Hal ini sesuai dengan penjabaran dari Stern (1962 dalam Afandi \& Hartati, 2017:127) yang menyatakan, bahwa pembelian impulsif dapat timbul karena adanya kelebihan waktu dan uang yang dimiliki seseorang. Pernyataan tersebut juga didukung oleh pendapat dari Amanah \& Pelawi (2015:10) pembelian impulsif merupakan suatu tindakan dalam menghabiskan uang secara berlebihan dengan berbelanja barangbarang yang sebenarnya tidak dibutuhkan dan tidak ada di dalam daftar rencana pembelanjaan. Mahasiswa GenBI tersebut merupakan mahasiswa luar daerah yang mengaku datang ke pusat perbelanjaan (dalam hal ini supermarket) selain untuk membeli kebutuhan bulanan juga dikarenakan ingin refreshing akibat merasa jenuh menghadapi masalah perkuliahan, tidak jarang mereka melakukan pembelian ketika sedang melihat-lihat barang yang sangat mereka inginkan meski sebenarnya tidak sedang mereka butuhkan karena barang tersebut umumnya memiliki potongan harga. Hal ini sesuai dengan penjelasan dari Kurniasari (2020:2) yang menyatakan, bahwa alasan mahasiswa melakukan kegiatan berbelanja adalah sebagai pelampiasan, namun hal ini akan berujung pada perilaku konsumtif yang mengarah pada pembelian impulsif, hal ini biasanya dialami oleh mahasiswa rantau karena mereka menemukan kemudahan fasilitas dalam berbelanja. Akan tetapi, setelah melakukan pembelian tersebut, biasanya mahasiswa akan merasa menyesal. Hal ini sesuai pendapat Diba (2014 dalam Kurniasari, 2020:4) pembelian impulsif dapat berdampak negatif pada kehidupan di masa mendatang, seperti barang-barang yang telah dibeli banyak yang tidak terpakai, tanggungan hutang yang telah dipinjam dari teman, timbul penyesalan karena harga yang 
ditawarkan tempat lain lebih murah, penyesalan karena penampilan barang tidak sebanding dengan manfaatnya, serta uang saku habis sebelum periode yang telah direncanakan.

Pada masa remaja, biasanya seseorang meniru perilaku dari teman sebayanya karena ingin diakui dan dihargai keberadaannya. Sehingga, seseorang akan melakukan pembelian terhadap barang yang sebenarnya tidak sedang dibutuhkan. Oleh karena itu, Ernayanti \& Marheni (2019:233) menyatakan, bahwa pada akhirnya seorang individu akan melakukan pembelian impulsif karena keinginannya untuk menyesuaikan dengan kebiasaan dan norma kelompok. Merujuk dari penjabaran yang diungkapkan oleh Lusardi (2010 dalam Pratiwi, 2017:99) teman sebaya dapat dikatakan sebagai narasumber yang digunakan untuk membuat keputusan ketika membeli produk. Hal tersebut didukung oleh Pratiwi (2017:100) yang menyatakan, bahwa kebiasaan seseorang dalam berbelanja dalam suatu kelompok terjadi karena pengaruh informasi (information influence) yang berasal dari teman yang dapat dipercaya. Sesuai dengan pernyataan dari Putri (2019:6) yang menyatakan, bahwa pengalaman belanja yang dimiliki teman sebaya dapat dijadikan rekomendasi yang akurat bagi seseorang untuk melakukan pembelian. Penjelasan tersebut sesuai dengan pernyataan dari Fitrawaty \& Hasibuan (2018:22) yang menyebutkan, bahwa keputusan pembelian impulsif disebabkan oleh adanya stimulus yang diberikan teman sebaya, bahkan sebagian orang melakukan pembelian impulsif karena termotivasi untuk menjadi serupa dengan teman sebayanya. Artinya, semakin sering mahasiswa memperoleh informasi mengenai suatu produk dari teman sebayanya, maka akan meningkatkan kecenderungan untuk melakukan pembelian impulsif. Adapun indikator yang digunakan untuk mengukur intensitas informasi teman sebaya antara lain: 1) pemberian informasi yang diperoleh dari teman sebaya ketika berbelanja; 2) teman sebaya sebagai panutan seseorang dalam pemilihan produk; 3) tuntutan untuk menyesuaikan dengan kelompok; 4) proses perbandingan sosial, serta; 5) ketergantungan kepada teman sebaya dalam melakukan keputusan pembelian.

Pemahaman mengenai ilmu ekonomi berupa literasi ekonomi sangat diperlukan dalam penerapan kehidupan sehari-hari karena pembelian impulsif merupakan jenis pembelian irasional. Berdasarkan pendapat dari Pratiwi (2017:99) literasi ekonomi atau yang bisa diartikan sebagai pemahaman paling mendasar mengenai ekonomi adalah suatu penerapan dari hasil yang didapat dari proses belajar yang dijadikan pilihan oleh mahasiswa agar dapat menjadi seorang konsumen yang bersikap rasional karena mengajarkan cara-cara membuat keputusan berdasarkan pertimbangan tertentu dari pilihan yang ada. Sesuai dengan pernyataan dari Ahman (2007:13 dalam Pratiwi, 2017:99) yang dimaksud "pilihan" disini dapat diartikan sebagai suatu tindakan saat membuat keputusan untuk menentukan barang yang akan dibeli. Mayoritas mahasiswa GenBI Universitas Negeri Malang berasal dari fakultas ekonomi. Artinya, mereka telah memperoleh pemahaman literasi ekonomi dari proses belajar di perguruan tinggi. Merujuk pada pendapat yang disampaikan oleh Fitrawaty \& Hasibuan (2018:22) pada perguruan tinggi, mahasiswa telah menjalani proses pembelajaran dari mata kuliah seperti teori ekonomi mikro dan makro yang merupakan bagian dari konsep dasar ekonomi. Oleh karena itu, Oktavia (2019:7) menyimpulkan, bahwa pembelian impulsif yang terjadi secara tiba-tiba dapat dicegah apabila setiap orang memiliki pemahaman tentang literasi ekonomi yang baik, sehingga ia akan memikirkan akibat yang akan diperolehnya apabila melakukan pembelian atas suatu barang tersebut dengan mempertimbangkan manfaat atau keuntungan yang akan diperolehnya. Adapun indikator yang digunakan untuk mengukur literasi ekonomi berdasarkan indikator yang disediakan oleh NCEE (The National Council on Economic Education). 
Merujuk pada pemaparan dari Rodin (dalam Utami \& Sumaryono, 2008:48 dalam Larasati \& Budiani, 2014:2) sebenarnya, pembelian impulsif juga dapat dikurangi atau bahkan dicegah apabila individu mempunyai kontrol diri yang ada pada dirinya. Adapun langkah yang dapat dilaksanakan adalah dengan cara membuat perencanaan mengenai apa saja barang yang harus dibeli untuk diprioritaskan terlebih dahulu, sehingga hal tersebut dapat membantu mencegah terjadinya pembelian impulsif. Menurut Pratiwi (2017:100) kontrol diri diterjemahkan sebagai suatu aktivitas seseorang dalam mengendalikan perilakunya yang berhubungan dengan cara seseorang mengendalikan emosi dan dorongan yang timbul dari dalam dirinya. Berdasarkan hasil penelitian yang dilaksanakan oleh Afandi \& Hartati (2017:126) yang menyatakan, bahwa kontrol diri mempunyai hubungan yang negatif dengan pembelian impulsif. Artinya, semakin tinggi kemampuan mengontrol diri pada seseorang akan berakibat pada kecenderungan pembelian impulsif yang semakin rendah. Adapun indikator yang digunakan untuk mengukur kontrol diri antara lain: 1) kemampuan mengontrol perilaku ketika menemukan suatu produk.; 2) kemampuan menilai produk dengan pengetahuan yang dimiliki; 3) kemampuan mengontrol informasi dari suatu produk; 4) kemampuan mengontrol pengalaman masa lalu dalam hal berbelanja; 5) kemampuan mengontrol keputusan pembelian.

Oleh sebab itu, berdasarkan latar belakang masalah tersebut, peneliti tertarik untuk mengambil penelitian dengan judul "Pengaruh Teman Sebaya, Literasi Ekonomi, dan Kontrol Diri terhadap Pembelian Impulsif pada GenBI Universitas Negeri Malang Periode 2020-2021”.

\section{Metode}

Pada penelitian ini, peneliti akan mempergunakan jenis penelitian deskriptif dengan metode kuantitatif, di mana penelitian ini nantinya dilakukan agar dapat mengukur dan menganalisis ada tidaknya pengaruh dari teman sebaya $\left(\mathrm{X}_{1}\right)$, literasi ekonomi $\left(\mathrm{X}_{2}\right)$, dan kontrol diri $\left(\mathrm{X}_{3}\right)$, terhadap pembelian impulsif $(\mathrm{Y})$. Populasi yang dipergunakan dalam penelitian ini merupakan mahasiswa GenBI Universitas Negeri Malang Periode 2020-2021 yang berjumlah sebanyak 75 orang. Para mahasiswa GenBI Universitas Negeri Malang mayoritas berasal dari Fakultas Ekonomi. Rentang usia populasi yang dipergunakan pada penelitian ini antara 20 tahun s/d 22 tahun. Karena jumlah populasi yang diambil berjumlah kurang dari 100 orang, oleh sebab itu sampel dari penelitian ini merupakan sampel jenuh,

Pada penelitian ini, peneliti menggunakan jenis data primer berupa kuesioner dan tes. Angket yang digunakan berupa angket tertutup, menggunakan skala Likert, dan dipergunakan untuk mengukur variabel teman sebaya $\left(\mathrm{X}_{1}\right)$, kontrol diri $\left(\mathrm{X}_{3}\right)$, dan pembelian impulsif $(\mathrm{Y})$. Sedangkan, tes dipergunakan untuk mengukur mengenai tingkat variabel literasi ekonomi respondenyang berjumlah 20 soal, maka skor untuk setiap butir soal bernilai 1 poin. Kuesioner dan tes tersebut nantinya akan dibagikan kepada seluruh responden secara daring dikarenakan adanya pandemi Covid-19 berupa link dari Google Form yang akan dikirimkan ke nomor Whatsapp setiap responden. Adapun teknik analisis data yang dipergunakan antara lain analisis deskriptif, uji asumsi klasik, serta uji regresi linear berganda. 


\section{Hasil dan Pembahasan}

\subsection{Hasil}

\subsubsection{Analisis Deskriptif}

Berdasarkan analisis deskriptif, diputuskan bahwa GenBI Universitas Negeri Malang periode 2020-2021 memiliki intensitas informasi teman sebaya yang cukup dengan persentase sejumlah 40\%; literasi ekonomi yang sangat tinggi dengan persentase sejumlah 62,7\%; kontrol diri yang tinggi dengan persentase sejumlah $42 \%$; serta pembelian impulsif yang cukup dengan persentase sejumlah $46,7 \%$.

\subsubsection{Uji Asumsi Klasik}

Tabel 1. Hasil Uji Normalitas

$\frac{\text { Asymp. Sig. (2 tailed) }}{, 200^{\mathrm{c}, \mathrm{d}}}$

Uji normalitas yang ditunjukkan pada tabel One-Sample Kolmogorov-Smirnov Test pada bagian Asymp. Sig (2-tailed) bernilai 0,200. Artinya, karena nilai dari Asymp. Sig. (2-tailed) lebih besar dari $\alpha(0,05)$, sehingga diputuskan bahwa data telah berdistribusi normal.

Tabel 2. Hasil Uji Multikolinearitas

\begin{tabular}{lcc}
\hline \multirow{2}{*}{ Variabel } & \multicolumn{2}{c}{ Collinearity Statistics } \\
\cline { 2 - 3 } & \multicolumn{2}{c}{ Tolerance } \\
\hline Intensitas informasi teman sebaya & 0,901 & 1,110 \\
Literasi ekonomi & 0,846 & 1,182 \\
Kontrol diri & 0,804 & 1,243 \\
\hline
\end{tabular}

Nilai tolerance dari ketiga variabel bebas menunjukkan angka $>0,10$ dan nilai VIF $<10$. Maka dari itu, dapat diputuskan bahwa tidak terjadi hubungan multikolineritas dalam penelitian ini.

Tabel 3. Hasil Uji Heteroskedastisitas

\begin{tabular}{lc}
\hline \multicolumn{1}{c}{ Variabel } & Sig. \\
\hline Intensitas informasi teman sebaya & 0,333 \\
Literasi ekonomi & 0,508 \\
Kontrol diri & 0,446 \\
\hline
\end{tabular}

Nilai Signifikansi dari ketiga variabel $>\alpha(0,05)$. Oleh sebab itu, dari model regresi yang dipergunakan pada penelitian yang telah peneliti lakukan bersifat homoskedastisitas. 


\subsubsection{Uji Regresi Linear Berganda}

Tabel 4. Hasil Uji Analisis Regresi Linear Berganda

\section{Coefficients $^{\mathrm{a}}$}

\begin{tabular}{|c|c|c|c|c|c|c|c|c|}
\hline Model & $\begin{array}{l}\text { Unstan } \\
\text { Coeffici } \\
\text { B }\end{array}$ & $\begin{array}{l}\text { ardized } \\
\text { hts } \\
\text { Std. } \\
\text { Error }\end{array}$ & $\begin{array}{l}\text { Standardiz } \\
\text { ed } \\
\text { Coefficients } \\
\text { Beta }\end{array}$ & $\mathrm{T}$ & Sig. & $\begin{array}{l}\text { Correl } \\
\text { Zero- } \\
\text { order }\end{array}$ & $\begin{array}{l}\text { tions } \\
\text { Partial }\end{array}$ & Part \\
\hline 1 (Constant & 24,158 & 3,472 & & 6,958 & ,000 & & & \\
\hline $\begin{array}{l}\text { Intensitas } \\
\text { informas } \\
\text { i_teman_s } \\
\text { ebaya }\end{array}$ & 399 & ,064 & 498 & 6,243 & ,000 & 639 & ,595 & ,473 \\
\hline $\begin{array}{l}\text { Literasi_e } \\
\text { konomi }\end{array}$ &,- 059 & ,024 &,- 201 & $-2,446$ & ,017 &,- 431 &,- 279 & -,185 \\
\hline $\begin{array}{l}\text { Kontrol_d } \\
\text { iri }\end{array}$ &,- 263 & ,066 &,- 335 & $-3,970$ & ,000 &,- 561 &,- 426 &,- 301 \\
\hline
\end{tabular}

a. Dependent Variable: Pembelian_impulsif

Berdasarkan tabel Coefficients ${ }^{a}$ di atas, dapat dibuat model regresi linear berganda seperti yang disajikan di bawah ini:

$$
Y=24,158+0,399 X_{1}-0,059 X_{2}-0,263 X_{3}
$$

\subsubsection{Uji Hipotesis Penelitian}

Merujuk pada tabel 4, didapatkan hasil nilai signifikansi variabel intensitas informasi teman sebaya sebesar 0,000 kurang dari $\alpha(0,05)$. Maknanya, intensitas informasi teman sebaya berpengaruh signifikan terhadap pembelian impulsif secara parsial pada GenBI Universitas Negeri Malang periode 2020-2021. Oleh karena itu, hasil penelitian ini sesuai dengan hipotesis pertama yang telah dibuat $\left(\mathrm{H}_{1}=\mathrm{p} x_{1} y \neq 0\right)$. Nilai signifikansi dari literasi ekonomi sebesar 0,017 kurang dari $\alpha(0,05)$. Maknanya, literasi ekonomi berpengaruh signifikan terhadap pembelian impulsif secara parsial pada GenBI Universitas Negeri Malang periode 2020-2021. Oleh karena itu, hasil penelitian ini sesuai dengan hipotesis kedua yang telah dibuat $\left(\mathrm{H}_{2}=\mathrm{p} x_{2} y \neq 0\right)$. Nilai signifikansi kontrol diri sebesar 0,000 kurang dari $\alpha(0,05)$. Maknanya, kontrol diri berpengaruh signifikan terhadap pembelian impulsif secara parsial pada GenBI Universitas Negeri Malang periode 2020-2021. Oleh karena itu, hasil penelitian ini sesuai dengan hipotesis ketiga yang telah dibuat $\left(\mathrm{H}_{3}=\mathrm{p} x_{3} y \neq 0\right)$.

\section{Tabel 5. Hasil Uji Simultan}

ANOVA

\begin{tabular}{lllllll}
\hline Model & Sum of Squares & Df & Mean Square & F & Sig. \\
\hline 1 & Regression & 1099,923 & 3 & 366,641 & 34,495 &, $000^{\mathrm{b}}$ \\
& Residual & 754,645 & 71 & 10,629 & & \\
& Total & 1854,568 & 74 & & & \\
\hline
\end{tabular}

a. Dependent Variable: Pembelian_impulsif

b. Predictors: (Constant), Intensitas_informasi_teman_sebaya, Literasi_ekonomi, Kontrol_diri 
Nilai signifikansi dari tabel $A_{n o v a^{a}}$ menunjukkan angka sebesar 0,000. Maksudnya, nilai signifikansi lebih kecil dari $\alpha(0,05)$. Maknanya, teman sebaya, literasi ekonomi, serta kontrol diri berpengaruh terhadap pembelian impulsif secara simultan pada GenBI Universitas Negeri Malang periode 2020-2021. Dengan demikian, diperoleh keputusan bahwa, hasil penelitian ini sesuai dengan hipotesis keempat yang telah dibuat $\left(\mathrm{H}_{4}=\mathrm{p} x_{4} y \neq 0\right)$.

\subsubsection{Sumbangan Efektif}

Tabel 6. Hasil Penghitungan Sumbangan Efektif (SE)

\begin{tabular}{lllc}
\hline \multicolumn{1}{c}{ Variabel } & $\begin{array}{c}\text { Standardized } \\
\text { Coefficients } \\
\text { Beta }\end{array}$ & $\begin{array}{c}\text { Zero } \\
\text { Order }\end{array}$ & $\begin{array}{c}\text { SE } \\
\left(\text { Beta }\left(\mathrm{X}_{n}\right) \times \text { Zero Order }\right. \\
\left(\mathrm{X}_{n}\right) \times 100 \%\end{array}$ \\
\hline $\begin{array}{l}\text { Intensitas_informasi_t } \\
\text { eman_sebaya }\left(\mathrm{X}_{1}\right)\end{array}$ & 0,498 &, 639 & $31,8222 \%$ \\
Literasi_ekonomi $\left(\mathrm{X}_{2}\right)$ & $-0,201$ &,- 431 & $8,6631 \%$ \\
Kontrol_diri $\left(\mathrm{X}_{3}\right)$ & $-0,335$ &,- 561 & $18,7935 \%$ \\
\multicolumn{2}{c}{ SE Total = R Square } & & $59,3 \%$ \\
\hline
\end{tabular}

Berdasarkan hasil kalkulasi dari sumbangan efektif di atas, diperoleh hasil bahwa variabel independen yang dapat berpengaruh terhadap pembelian impulsif (Y) secara dominan pada GenBI Universitas Negeri Malang periode 2020-2021 adalah variabel intensitas informasi teman sebaya $\left(\mathrm{X}_{1}\right)$ sebesar $31,8222 \%$.

\subsubsection{Uji Determinasi R Square}

Tabel 7. Hasil Uji F dengan SPSS versi 25.00

\begin{tabular}{lllll}
\multicolumn{4}{c}{ Model Summary } \\
\hline Model & R & R Square & Adjusted R Square & Std. Error of the Estimate \\
\hline 1 &, $770^{\text {a }}$ &, 593 &, 576 & 3,26018 \\
\hline
\end{tabular}

a. Predictors: (Constant), Intensitas_informasi_teman_sebaya, Literasi_ekonomi, Kontrol_diri

Nilai koefisien determinasi ( $R$ Square $\left(\mathrm{R}^{2}\right)$ ) berdasarkan tabel Model Summary di atas adalah 0,593 , artinya variasi dari variabel bebas (intensitas informasi teman sebaya $\left(X_{1}\right)$, literasi ekonomi $\left(\mathrm{X}_{2}\right)$, dan kontrol diri $\left(\mathrm{X}_{3}\right)$ ) dapat menjelaskan atau mempengaruhi variabel dependen (pembelian impulsif) sebesar 59,3\%, sisanya sebesar 40,7\% (100\% - 59,3\%) dipengaruhi oleh faktor lain diluar variabel bebas yang diteliti.

\subsection{PEMBAHASAN}

\subsubsection{Pengaruh Intensitas Informasi Teman Sebaya terhadap Pembelian Impulsif pada GenBI Universitas Negeri Malang Periode 2020-2021}

Dalam penelitian yang telah dilaksanakan kepada GenBI Universitas Negeri Malang periode 2020/2021, variabel intensitas informasi teman sebaya merupakan variabel bebas yang paling unggul dalam mempengaruhi pembelian impulsif. Berdasarkan analisis penelitian, diperoleh hasil bahwa intensitas informasi teman sebaya dapat mempengaruhi pembelian impulsif pada GenBI Universitas Negeri Malang periode 2020-2021. Hasil dalam penelitian ini 
sesuai dengan hasil penelitian dari Ernayanti dan Marheni (2019: 231) konformitas teman sebaya secara parsial dapat mempengaruhi impulsive buying pada remaja putri di Denpasar. Penelitian lain yang memperoleh hasil serupa berasal dari Oktavia (2019:6) yang menjelaskan bahwa, secara parsial persepsi teman sebaya dapat berpengaruh terhadap pembelian impulsif. Hasil penelitian lain yang sependapat dijelaskan Pratiwi (2017:101) yang menunjukkan bahwa teman sebaya memiliki hubungan yang positif terhadap pembelian impulsif dalam produk fashion. Merujuk dari pemaparan yang disampaikan oleh Pratiwi (2017:105) pembelian impulsif dapat terjadi karena adanya komunikasi antar anggota kelompok, mereka saling bertukar informasi yang dapat diterima dan dipercaya, sehingga terjadi perubahan pandangan, perangai, serta tingkah laku. Individu biasanya lebih nyaman berbelanja dengan teman sebayanya. Rasa nyaman inilah yang mengakibatkan seseorang tertarik dalam hal meniru gaya dan perilaku teman sebayanya, akibatnya secara tidak sadar ia akan melakukan pembelian yang tidak terduga, pemaparan inilah yang diungkapkan oleh Putri (2019:11). Pemberian informasi yang diperoleh dari teman sebaya ketika berbelanja dapat mempengaruhi keputusan pembelian individu. Pendapat tersebut sejalan dengan pemikiran yang telah diutarakan oleh Oktavia (2019:7) yang menjelaskan bahwa, pembelian impulsif pada seseorang dapat terjadi akibat pengaruh dari teman sebaya karena orang tersebut memperoleh informasi yang berasal dari teman sebayanya dan ia mempercayai informasi tersebut. Lebih lanjut, Lusardi (2010 dalam Pratiwi, 2017:99) yang mengungkapkan bahwa, peer group adalah narasumber yang dapat memberikan informasi dan saran kepada seseorang dalam pengambilan keputusan terhadap pembelian suatu barang. Pendapat tersebut sejalan dengan pemaparan dari Putri (2019:11) yang menyatakan bahwa, ketika mahasiswa melakukan pembelian tanpa adanya pertimbangan akibat dipengaruhi oleh teman, hal ini tergolong sebagai pembelian impulsif.

\subsubsection{Pengaruh Literasi Ekonomi terhadap Pembelian Impulsif pada GenBI Universitas Negeri Malang Periode 2020-2021}

Berdasarkan hasil penelitian, diperoleh hasil bahwa literasi ekonomi dapat mempengaruhi pembelian impulsif pada GenBI Universitas Negeri Malang periode 2020-2021. Hasil tersebut sejalan dengan hasil penelitian Oktavia (2019:6) yang mengungkapkan bahwa, secara parsial literasi ekonomi memiliki pengaruh terhadap pembelian impulsif. Hasil penelitian serupa juga diperoleh dari hasil penelitian Pratiwi (2019:105) yang memutuskan bahwa, literasi ekonomi memiliki korelasi positif dengan pembelian impulsif pada produk fashion. Pemahaman mengenai literasi ekonomi dapat dilihat dari kepandaian seseorang dalam melakukan pengelolaan terhadap keuangannya dengan mengacu pada hasil pembelajaran yang telah mereka lakukan sebelumnya, hal ini membuat individu menjadi paham persoalan mengenai kebutuhan yang memang benar-benar harus didahulukan, akibatnya akan menjadikan mereka seorang konsumen yang dapat memutuskan pembelian secara rasional. Hal ini dikarenakan dalam indikator yang dipergunakan untuk mengukur literasi ekonomi dalam penelitian yang berpedoman pada 20 indikator yang telah disediakan oleh NCEE salah satunya berisi materi mengenai cara mengatur penghasilan perorangan dan cara menganalisis tingkat harga terhadap kecenderungan menabung hal ini akan berdampak dalam hal melakukan kegiatan konsumsi. Merujuk pada pendapat Pratiwi (2017:99) bahwa, literasi ekonomi atau yang bisa diartikan sebagai pemahaman paling mendasar mengenai ekonomi (melek ekonomi) adalah suatu penerapan dari hasil yang didapat dari proses belajar yang dijadikan pilihan oleh mahasiswa agar dapat menjadi seorang konsumen yang bersikap 
rasional, hal ini dikarenakan literasi ekonomi mengajarkan cara-cara membuat keputusan berdasarkan pertimbangan tertentu berdasarkan pilihan yang ada. Mayoritas mahasiswa GenBI Universitas Negeri Malang berasal dari fakultas ekonomi. Artinya, mereka telah memperoleh pemahaman literasi ekonomi dari proses belajar di perguruan tinggi. Pernyataan tersebut sejalan dengan pendapat yang disampaikan oleh Fitrawaty \& Hasibuan (2018:22) pada perguruan tinggi, mahasiswa telah menjalani proses pembelajaran dari mata kuliah seperti konsep ekonomi mikro dan makro yang menjadi bagian dari konsep dasar ekonomi. Sesuai dengan penjelasan dari Maharani (2018:228) yang menyatakan bahwa, apabila literasi ekonomi yang individu miliki tinggi, maka akan membuatnya melakukan perilaku konsumsi yang semakin rasional. Oleh karena itu, menurut Oktavia (2019:7) apabila seseorang memiliki pemahaman mengenai literasi ekonomi, maka ia akan memperhitungkan hal positif dan negatif yang akan terjadi jika ia melakukan pembelian impulsif. Meskipun GenBI Universitas Negeri Malang periode 2020-2021 tidak semuanya berasal dari Fakultas Ekonomi, tetapi mereka memperoleh ilmu ekonomi dari seminar-seminar yang telah dilakukan pada kegiatan GenBI itu sendiri.

\subsubsection{Pengaruh Kontrol Diri terhadap Pembelian Impulsif pada GenBI Universitas Negeri Malang Periode 2020-2021}

Berdasarkan hasil penelitian, diketahui bahwa kontrol diri dapat mempengaruhi pembelian impulsif pada GenBI Universitas Negeri Malang periode 2020/2021. Hasil ini sesuai dengan penelitian Afandi \& Hartati (2017:126) yang mengungkapkan bahwa dalam analisis persamaan regresi linear sederhana diperoleh hasil bahwa kontrol diri menunjukkan arah yang negatif. Putri (2019:9) juga menghasilkan keputusan yang sama, dimana penelitiannya membuktikan bahwa, variabel kontrol diri memiliki pengaruh yang negatif terhadap pembelian impulsif. Hasil penelitian serupa juga diperoleh Larasati \& Budiani (2014:5) yang menunjukkan bahwa, kontrol diri memiliki korelasi negatif dengan pembelian impulsif, artinya apabila kontrol diri yang ada dalam diri seseorang termasuk tinggi, maka ia akan terhindar dari pembelian impulsif. Seseorang dengan kontrol diri yang lemah biasanya disebabkan oleh adanya ego-depleted (kondisi seseorang ketika mengalami kelelahan dan berkurangnya potensi dalam mengontrol diri sendiri). Pernyataan tersebut sesuai pendapat Baumister, et all. (2008 dalam Afandi \& Hartati, 2017:127) yang mengungkapkan bahwa, apabila kemampuan kontrol diri pada individu mengalami penurunan (ego-depletion) saat sedang melakukan kegiatan berbelanja, maka ia cenderung tidak memikirkan dampak atas pembelian yang dilakukannya. Apabila kemampuan kontrol diri yang dimiliki seseorang menurun, hal tersebut akan membuatnya mudah terpersuasi. Pernyataan tersebut sejalan dengan data wawancara yang telah dijalankan oleh Afandi \& Hartati (2017:124) yang menyebutkan, bahwa konsumen cenderung mencari produk yang memiliki potongan harga. Kontrol diri dapat membuat seseorang mampu menahan dan mengendalikan stimulus dan keinginan yang berasal dari dalam dirinya, sehingga ia akan lebih berhati-hati ketika akan melakukan keputusan terhadap suatu pembelian. Kemampuan mengontrol informasi dari suatu produk penting diterapkan agar nantinya tidak akan menimbulkan dampak negatif pada kehidupan di masa mendatang, seperti barang-barang yang telah dibeli banyak yang tidak terpakai, tanggungan hutang yang telah dipinjam dari teman, timbul penyesalan karena harga yang ditawarkan tempat lain lebih murah, penyesalan karena penampilan barang tidak sebanding dengan manfaatnya, serta uang saku habis sebelum periode yang telah direncanakan. Pernyataan yang sejalan juga dipaparkan dalam hasil penelitian yang dilaksanakan oleh Rook \& Hoch (1985 dalam Afandi \& Hartati, 
2017:125) menjelaskan, bahwa pembelian impulsif dapat mengakibatkan terjadinya penyesalan setelah melakukan pembelian, antara lain berkurangnya keuangan pribadi, kepuasan yang menurun, serta dapat mempengaruhi harga diri (self-esteem).

\subsubsection{Pengaruh Intensitas Informasi Teman Sebaya, Literasi Ekonomi, dan Kontrol Diri terhadap Pembelian Impulsif pada GenBI Universitas Negeri Malang Periode 2020-2021}

Berdasarkan hasil penelitian, diperoleh hasil bahwa intensitas informasi teman sebaya, literasi ekonomi, dan kontrol diri dapat mempengaruhi pembelian impulsif pada GenBI Universitas Negeri Malang periode 2020-2021. Hasil ini searah dengan hasil penelitian dari Pratiwi (2017:102) yang menyatakan bahwa, seluruh variabel independen dalam penelitian tersebut (literasi ekonomi, teman sebaya, dan kontrol diri) dinyatakan berpengaruh terhadap variabel dependen (pembelian impulsif) secara simultan. Hal tersebut sejalan dengan hasil penelitian yang telah dilaksanakan oleh Pratiwi (2017:105) merujuk pada hasil penelitian, dapat dinyatakan bahwa literasi ekonomi, teman sebaya, serta kontrol diri dapat mempengaruhi pembelian impulsif dari produk fashion, baik secara parsial maupun secara simultan pada mahasiswa Jurusan Pendidikan Ekonomi Undiksha. Merujuk pada pendapat Amanah \& Pelawi (2015:10) pembelian impulsif merupakan suatu tindakan berlebihan dalam menghabiskan uang dengan berbelanja produk yang sebenarnya tidak diperlukan dan tidak ada di dalam daftar rencana pembelanjaan. Mahasiswa GenBI tersebut merupakan mahasiswa luar daerah yang mengaku datang ke pusat perbelanjaan (dalam hal ini supermarket) selain untuk membeli kebutuhan bulanan juga dikarenakan ingin refreshing akibat merasa jenuh menghadapi masalah perkuliahan, tidak jarang mereka melakukan pembelian ketika sedang melihat-lihat barang yang sangat mereka inginkan meski sebenarnya tidak sedang mereka butuhkan karena barang tersebut umumnya memiliki potongan harga. Hal ini sesuai dengan penjelasan dari Kurniasari (2020:2) yang menyatakan, bahwa alasan mahasiswa melakukan kegiatan berbelanja adalah sebagai pelampiasan, namun hal ini akan berujung pada perilaku konsumtif yang mengarah pada pembelian impulsif, hal ini biasanya dialami oleh mahasiswa rantau karena mereka menemukan kemudahan fasilitas dalam berbelanja. Pernyataan tersebut sejalan dengan adanya pendapat dari Bitta (1993 dalam Ernayanti \& Marheni, 2019:233) yang menyatakan, bahwa kegemaran seseorang untuk mengunjungi pusat perbelanjaan modern telah meningkat. Menurut pendapat Diba (2014 dalam Kurniasari, 2020:4) pembelian impulsif dapat berdampak negatif pada kehidupan di masa mendatang, seperti barang-barang yang telah dibeli banyak yang tidak terpakai, tanggungan hutang yang telah dipinjam dari teman, timbul penyesalan karena harga yang ditawarkan tempat lain lebih murah, penyesalan karena penampilan barang tidak sebanding dengan manfaatnya, serta uang saku habis sebelum periode yang telah direncanakan. Menurut pendapat yang dipaparkan oleh Putri (2019:6) individu biasanya percaya dengan informasi dan saran yang diberikan temannya ketika melakukan keputusan pembelian karena teman tersebut telah memiliki pengalaman berbelanja barang yang dimaksud, sehingga dipercaya dapat dijadikan rekomendasi yang cocok. Sehingga, semakin sering seseorang berinteraksi dengan teman sebayanya, maka dorongan untuk melakukan pembelian impulsif juga akan semakin tinggi. Oleh karena itu, untuk mencegah terjadinya pembelian impulsif, Pratiwi (2017:99) mengungkapkan bahwa, literasi ekonomi sangat krusial bagi individu, hal ini akan mencegah mahasiswa untuk melakukan perilaku konsumtif dalam berkonsumsi. Apabila literasi ekonomi yang dimiliki seseorang semakin tinggi, maka semakin sedikit peluang orang tersebut akan 
mengalami pembelian impulsif. Oleh sebab itu, Putri (2019: 10) juga menyatakan pendapatnya, bahwa seseorang yang memiliki potensi yang baik dalam melakukan kontrol diri, umumnya akan sanggup mengendalikan dorongan yang berasal dari dalam dirinya, sehingga ia dapat mengontrol perilakunya dalam berkonsumsi. Seseorang akan melakukan banyak pertimbangan terlebih dahulu sebelum mengambil keputusan dalam melakukan pembelian. Meskipun intensitas informasi teman sebaya tinggi, namun apabila GenBI Universitas Negeri Malang periode 2020-2021 memiliki kontrol diri yang baik dan mampu menerapkan pemahaman literasi ekonomi yang berasal dari proses pembelajaran selama di perguruan tinggi, seharusnya kecenderungan pembelian impulsif dapat dihindari, karena mereka dapat berkonsumsi dengan rasional.

\section{Simpulan}

Merujuk pada hipotesis dan hasil analisis, maka diperoleh kesimpulan bahwa intensitas informasi teman sebaya berhubungan positif dengan pembelian impulsif pada GenBI Universitas Negeri Malang Periode 2020-2021. Artinya, semakin sering mahasiswa GenBI memperoleh informasi mengenai suatu barang ketika berbelanja bersama dengan teman sebaya, maka akan semakin meningkatkan kecenderungan untuk melakukan pembelian impulsif. Variabel teman sebaya pada penelitian ini adalah yang memberikan sumbangan efektif paling dominan dalam mempengaruhi pembelian impulsif, begitu pula sebaliknya. Literasi ekonomi berhubungan negatif pembelian impulsif pada GenBI Universitas Negeri Malang Periode 2020-2021. Artinya, semakin tinggi tingkat literasi ekonomi yang dimiliki mahasiswa GenBI, maka kecenderungan untuk melakukan pembelian impulsif akan menurun apabila mereka mampu untuk menerapkan pemahaman literasi ekonomi ketika akan memutuskan suatu pembelian, begitu pula sebaliknya. Kontrol diri berhubungan negatif dengan pembelian impulsif pada GenBI Universitas Negeri Malang Periode 2020-2021. Artinya, semakin baik kemampuan kontrol diri yang dimiliki mahasiswa GenBI, maka kecenderungan untuk melakukan pembelian impulsif akan menurun, begitu pula sebaliknya. Variasi dari teman sebaya, literasi ekonomi, dan kontrol diri dapat mempengaruhi pembelian impulsif pada GenBI Universitas Negeri Malang Periode 2020-2021. Variasi ketiga variabel independen dapat menjelaskan pembelian impulsif sebesar 59,3\%. Meskipun intensitas informasi yang diperoleh dari teman sebaya mengenai suatu barang tinggi, namun apabila mahasiswa GenBI memiliki kemampuan kontrol diri yang baik serta mampu menerapkan pemahaman literasi ekonomi yang dimiliki, maka mereka akan mempertimbangkan manfaat serta biaya yang harus dikeluarkan sebelum memutuskan membeli suatu barang, sehingga mereka tetap bisa berbelanja secara rasional dan terhindar dari pembelian impulsif, begitu pula sebaliknya.

\section{Daftar Rujukan}

Afandi, Ardian Rahman, dan Sri Hartati. (2017). Pembelian Impulsif pada Remaja Akhir Ditinjau dari Kontrol Diri. Gadjah Mada Journal of Psychology (GamaJoP), 3(3), 123-130. Dari https://journal.ugm.ac.id/gamajop/article/download/44103/23970.

Amanah, Dita dan Stephany P. Pelawi. (2015). Pengaruh Promosi Penjualan (Sales Promotion) dan Belanja Hedonis (Hedonic Shopping) terhadap Impulsive Buying Produk Matahari Plaza Medan Fair. Jurnal Quranomic, 3(02), 10-18. Dari https://ejournal.gunadarma.ac.id/index.php/ekbis/article/view/2343.

Angeline, Mervin. (2017). Pengaruh Promosi dalam Mempengaruhi Pembelian Tanpa Perencanaan (Impulse Buying) pada Suzuya Medan. Jurnal Ilmiah SMART, 1(1), 11-19. Dari http://www.stmbmultismart.ac.id/ejournal/index.php/JMBA/article/view/2/3.

Chandra, I Komang Agus Hari dan Ni Made Purnami. (2014). Pengaruh Jenis Kelamin, Promosi Penjualan dan Sifat Materialisme terhadap Perilaku Impulse Buying secara Online. E-Jurnal Manajemen Universitas 
Udayana,

$3(8)$,

2331-2348.

Dari

https://ojs.unud.ac.id/index.php/Manajemen/article/download/8657/7162.

Diba, Dira Sarah. (2013). Peranan Kontrol Diri terhadap Pembelian Impulsif pada Remaja Berdasarkan Perbedaan Jenis Kelamin di Samarinda. Psikoborneo, 1(3), 185-191. Dari http://ejournals.unmul.ac.id/index.php/psikoneo/article/download/3330/2260.

Ernayanti, Ni Made Desi dan Adijanti Marheni. (2019). Peran Konformitas Teman Sebaya dan Self Monitoring terhadap Impulsive Buying pada Remaja Madya Putri di Denpasar. Jurnal Psikologi Udayana, 226-236. Dari https://ocs.unud.ac.id/index.php/psikologi/article/download/47166/28342.

Fitrawaty dan Rea Dinda Aulia Hasibuan. (2018). Pengaruh Literasi Ekonomi dan Kelompok Teman Sebaya terhadap Perilaku Pembelian Impulsif untuk Produk Fashion pada Mahasiswa Pendidikan Ekonomi Angkatan 2015 di Fakultas Ekonomi Universitas Negeri Medan. Jurnal Ekodik: Ekonomi Pendidikan, 6(7), $21-27$.

Dari https://jurnal.unimed.ac.id/2012/index.php/ekodik/article/download/12088/10493.

Kosyu, Dayang Asning, dkk. (2014). Pengaruh Hedonic Shopping Motives terhadap Shopping Lifestyle dan Impulse Buying (Survei pada Pelanggan Outlet Stradivarius di Galaxy Mall Surabaya). Jurnal Administrasi $\quad$ Bisnis, $14(2), \quad 1-7 . \quad$ Dari http://administrasibisnis.studentjournal.ub.ac.id/index.php/jab/article/view/597.

Wurangian, Flinsia, Daisy Engka, dan Jacline Sumual. (2015). Analisis Pola Konsumsi Mahasiswa Fakultas Ekonomi \& Bisnis Universitas Sam Ratulangi Yang Kost Di Kota Manado. Jurnal Berkala Ilmiah Efisiensi, 15(02), 74-87. Dari https://ejournal.unsrat.ac.id/index.php/jbie/article/view/7658.

Kurniasari, Ayunita Fajar. (2020). Hubungan Kontrol Diri dan Teman Sebaya dengan Impulsive Buying. Skripsi Thesis, Universitas Muhammadiyah Surakarta, 1-16. Dari http://eprints.ums.ac.id/id/eprint/83283.

Larasati, Manggi Asih dan Meita Santi Budiani. (2014). Hubungan antara Kontrol Diri dengan Pembelian Impulsif Pakaian pada Mahasiswi Psikologi Universitas Negeri Surabaya yang Melakukan Pembelian secara Online. Character: Jurnal Penelitian Psikologi., 2(3), 1-8. Dari https://jurnalmahasiswa.unesa.ac.id/index.php/character/article/viewFile/11000/10528.

Lulu, Lorensia, Yohanes Bahari, dan Izhar Salim. (2019). Analisis Bantuan Bank Indonesia pada Program Kewirausahaan Generasi Baru Indonesia (GenBI) Kalimantan Barat. Jurnal Pendidikan dan Pembelajaran Khatulistiwa, 8(9),

https://jurnal.untan.ac.id/index.php/jpdpb/article/view/35749.

Maharani, Rosida. (2018). Pengaruh Modernitas dan Literasi Ekonomi Terhadap Perilaku Konsumsi Siswa Kelas XI IIS Di SMA Negeri 1 Talun. Jurnal Pendidikan Ekonomi (JUPE), 6(3), 222-229. Dari https://jurnalmahasiswa.unesa.ac.id/index.php/jupe/article/view/25240.

Mulyana, Andi Erna dan Atika Pertiwi N.I.. (2020). Pengaruh Promosi, Atmosfer Toko, dan Motivasi Belanja Hedonis terhadap Pembelian Impulsif Konsumen Ritel Modern di Kota Batam. Journal of Applied Business Administration, 4(1), 18-22. Dari https://jurnal.polibatam.ac.id/index.php/JABA/article/view/1938.

Noneng dkk. (2020). Pengaruh Literasi Ekonomi dan Lingkungan Sosial terhadap Perilaku Pembelian Impulsif Melalui Online Shop pada Peserta Didik Kelas X Jurusan IPS di SMA Negeri 8 Makassar. Jurnal Ekonomi, Sosial \& Humaniora, 2(02), 94-104. https://www.jurnalintelektiva.com/index.php/jurnal/article/download/294/205.

Nurmasarie, Rachma dan Sri Setyo Iriani. (2013). Pengaruh Promosi Penjualan dan Penjualan Perseorangan terhadap Keputusan Belanja Tidak Terencana. Jurnal Ilmu Manajemen (JIM), 1(2), 528-540. Dari https://jurnalmahasiswa.unesa.ac.id/index.php/jim/article/view/3038.

Oktavia, Riska. (2019). Pengaruh Literasi Ekonomi dan Persepsi Teman Sebaya terhadap Perilaku Pembelian Impulsif untuk Produk Fashion di Online Shop pada Siswa Kelas X Program Keahlian Pemasaran di SMK 17 Pare Kabupaten Kediri. Artikel Skripsi, Universitas Nusantara PGRI Kediri, 2-8. Dari http://simki.unpkediri.ac.id/mahasiswa/file_artikel/2019/14.1.01.04.0025.pdf.

Pratiwi, Indah. (2017). Pengaruh Literasi Ekonomi, Kelompok Teman Sebaya dan Kontrol Diri terhadap Perilaku Pembelian Impulsif untuk Produk Fashion di Online Shop pada Mahasiswa Jurusan Pendidikan Ekonomi Undiksha. Jurnal Pendidikan Ekonomi Undiksha, 9(1), 98-107. Dari https://ejournal.undiksha.ac.id/index.php/JJPE/article/viewFile/19994/11942.

Putri, Tamara Virsa dan Sri Setyo Iriani. (2020). Pengaruh Gaya Hidup Konsumtif dan Promosi Penjualan Terhadap Pembelian Impulsif Makanan Kekinian Mahasiswa Urban Surabaya. Jurnal Ilmu Manajemen, 8(4). Dari https://journal.unesa.ac.id/index.php/jim/article/view/9876. 
Putri, Nadea Rosi Atini. (2019). Hubungan Kontrol Diri dan Konformitas Teman Sebaya dengan Pembelian Impulsif Mahasiswa. Skripsi Thesis, Universitas Muhammadiyah Surakarta, 1-17. Dari http://eprints.ums.ac.id/id/eprint/74898.

Ratih, Ida Ayu Tryastiti dan Dewi Puri Astiti. (2016). Pengaruh Motivasi Hedonis dan Atmosfer Toko terhadap Pembelian Impulsif pada Remaja Putri di Denpasar. Jurnal Psikologi Udayana, 3(2), 209-219. Dari https://ojs.unud.ac.id/index.php/psikologi/article/view/25235.

Rozaini, Noni dan Bismi Aditya Ginting. (2019). Pengaruh Literasi Ekonomi dan Kontrol Diri terhadap Perilaku Pembelian Impulsif untuk Produk Fashion. NIAGAWAN, 8(1), 1-9. Dari https://jurnal.unimed.ac.id/2012/index.php/niagawan/article/viewFile/12795/1094.

Tupamahu, F. A. S., \& Balik, D. (2020). Efek Moderasi Kontrol Diri pada Hubungan Sifat Materialisme Terhadap Pembelian Impulsif Online. PUBLIC POLICY (Jurnal Aplikasi Kebijakan Publik \& Bisnis), 1(2), 115-136. 